\title{
Motivasi dan Beban Kerja Karyawan PT. Serambi Indonesia Terhadap Peningkatan Kinerja
}

\author{
Teuku Andi Roza, Razali Abdullah, Ibnu Kadar \\ Sekolah Tinggi Ilmu Ekonomi Sabang Banda Aceh, Universitas Serambi Mekah \\ Alumni Sekolah Tinggi Ilmu Ekonomi Sabang Banda Aceh \\ Email : Teukuandiroza99@gmail.com
}

\begin{abstract}
Abstrak
Motivasi merupakan faktor dasar yang mendorong seorang karyawan untuk bekerja dengan baik. Dengan adanya motivasi yang tinggi, maka seseorang akan memberikan usaha yang lebih di dalam melaksanakan pekerjaannya sehingga menghasilkan kinerja yang lebih baik. Tujuan penelitian ini untuk mengetahui Motivasi dan Beban Kerja Karyawan PT. Serambi Indonesia Terhadap Peningkatan Kinerja. Penelitian ini dilakukan di PT. Serambi Indonesia, pada tanggal 20-25 Februari 2019. Populasi dalam penelitian ini adalah seluruh karyawan pada PT. Serambi Indonesia yaitu sebanyak 150 orang. Sampel dalam penelitian ini adalah sejumlah 52 orang. Tahap pengumpulan data dimulai dengan responden terlebih dahulu diberi penjelasan maksud dan tujuan penelitian ini. Pengumpulan data primer dilakukan dengan memberikan kuesioner secara langsung kepada responden. Untuk mengetahui analisis secara statistik dengan menggunakan rumus persentase. Hasil penelitian membuktikan bahwa variabel motivasi diperoleh nilai rerata sebesar 3.88, atau responden menyatakan setuju bahwa faktor motivasi kerja karyawan pada PT. Serambi Indonesia akan berdampak terhadap peningkatan kinerja karyawan PT. Serambi Indonesia, dan variabel beban kerja karyawan PT. Serambi Indonesia diperoleh nilai rerata sebesar 4,31, atau responden menyatakan setuju bahwa beban kerja dapat berdampak terhadap peningkatan kinerja karyawan PT. Serambi Indonesia, serta variabel kinerja karyawan PT. Serambi Indonesia diperoleh nilai rerata sebesar 4,01, atau responden menyatakan setuju bahwa responden mempunyai persepsi yang positif terhadap kinerja karyawan, dimana motivasi dapat meningkatkan kinerja karyawan di PT. Serambi Indonesia.
\end{abstract}

Kata Kuci : Motivasi, Beban Kerja, Kinerja Karyawan

\section{PENDAHULUAN}

Motivasi kerja sangat dibutuhkan karyawan dalam peningkatan kinerjanya. Motivasi adalah segala sesuatu yang menimbulkan semangat atau dorongan kerja sehingga kuat atau lemahnya motivasi kerja karyawan akan menentukan kinerjanya. Pentingnya motivasi karena motivasi adalah hal yang menyebabkan, menyalurkan, dan mendukung perilaku manusia supaya mau bekerja giat dan antusias mencapai hasil yang optimal. Motivasi semakin penting karena manajer membagikan pekerjaan pada bawahannya untuk dikerjakan dengan baik dan terintegrasi kepada tujuan yang diinginkan (Hasibuan, 2007:141). Motivasi atau dorongan untuk bekerja ini sangat menentukan bagi tercapainya suatu tujuan, maka manusia harus dapat menumbuhkan motivasi kerja setinggi-tingginya bagi para karyawan dalam perusahaan.

Motivasi kerja muncul karena adanya dorongan kebutuhan yang dirasakan seseorang. Menurut McClelland jika kebutuhan seseorang sangat kuat maka motivasi 
orang tersebut bertambah untuk menggunakan perilaku yang mengarah ke pemuasan kebutuhannya (Robbins, 2006:215). Teori ini berfokus pada tiga kebutuhan yaitu kebutuhan akan prestasi (need for achievement), kebutuhan akan kekuasaan (need for power) dan kebutuhan berafiliasi (need for affiliation).

Kebutuhan akan prestasi merupakan kebutuhan seseorang untuk mengungguli dan melakukan sesuatu dengan lebih baik dari yang telah dilakukan sebelumnya. Kebutuhan akan kekuasaan merupakan keinginan untuk berpengaruh dan mengendalikan orang lain dan kebutuhan berafiliasi merupakan kebutuhan untuk bersosialisasi dan diterima baik oleh orang lain. Ketiga hal ini akan dapat memotivasi seseorang dalam bekerja sehingga dapat mendorong terjadinya peningkatan kinerja karyawan.

Setiap kegiatan yang dilakukan oleh seseorang termasuk karyawan didorong oleh suatu kekuasaan dalam diri orang tersebut, kekuatan pendorong inilah yang disebut motivasi. Motivasi kerja karyawan dalam suatu organisasi dapat dianggap sederhana dan dapat pula menjadi masalah yang kompleks, karena pada dasarnya manusia mudah untuk dimotivasi dengan memberikan apa yang menjadi keinginannya. Masalah motivasi kerja dapat menjadi sulit dalam menentukan imbalan dimana apa yang dianggap penting bagi seseorang karena sesuatu yang penting bagi seseorang belum tentu penting bagi orang lain. Bila seseorang termotivasi, ia akan berusaha berbuat sekuat tenaga untuk mewujudkan apa yang diinginkannya. Namun belum tentu upaya yang keras itu akan menghasilkan kinerja yang diharapkan, apabila tidak disalurkan dalam arah yang dikehendaki organisasi.

Manajemen sumber daya manusia adalah suatu proses yang menangani berbagai masalah pada ruang lingkup karyawan, karyawan, buruh, manajer dan tenaga kerja lainnya untuk dapat menunjang aktivitas organisasi atau perusahaan demi mencapai tujuan yang telah ditentukan. Manajemen sumber daya manusia adalah suatu prosedur yang berkelanjutan yang bertujuan untuk memasok suatu organisasi atau perusahaan dengan orang-orang yang tepat untuk ditempatkan pada posisi dan jabatan yang tepat pada saat organisasi memerlukannya.

Salah satu faktor yang dapat mempengaruhi peningkatan kinerja karyawan PT. Serambi Indonesia adalah adanya motivasi kerja karyawan yang masih rendah, yang dimiliki oleh karyawan. Motivasi kerja yang rendah yang dimiliki oleh karyawan PT. Serambi Indonesia saat ini menjadi salah satu faktor penghambat tercapainya tujuan secara individual dan tujuan secara organisasi. Hal ini dapat dilihat dari sikap karyawan yang cenderung malas untuk menyelesaikan pekerjaan yang telah menjadi tugas dan tanggung jawabnya masing-masing. Kemudian banyak karyawan yang hanya datang tepat waktu untuk absen elektrik dan setelah absen banyak karyawan yang keluar kantor untuk keperluan yang masih kurang jelas, sehingga hal ini berpengaruh pada tingkat kinerja karyawan yang rendah.

\section{TINJAUAN KEPUSTAKAAN \\ Motivasi Kerja}

Menurut Hasibuan (2012) motivasi berasal dari kata latin movere yang berarti dorongan atau daya penggerak. Motivasi diberikan kepada manusia, khususnya kepada para bawahan atau pengikut. Motivasi penting karena dengan motivasi ini diharapkan setiap individu karyawan mau bekerja keras dan antusias untuk mencapai produktivitas kerja yang tinggi. Motivasi adalah pemberian daya penggerak yang menciptakan 
kegairahan kerja seseorang agar mereka mau bekerja efektif dan terintegrasi dengan segala daya upayanya untuk mencapai kepuasan.

Menurut Wursanto (2012) motivasi adalah suatu kekuatan potensial yang ada dalam diri seorang manusia, yang dapat dikembangkannya sendiri atau dikembangkan oleh sejumlah kekuatan luar yang ada, intinya berkisar sekitar imbalan materi dan imbalan non materi, yang dapat mempengaruhi hasil kinerjanya secara positif atau secara negatif, dimana tergantung pada situasi dan kondisi yang dihadapi orang yang bersangkutan. Suatu dorongan jiwa yang membuat seseorang tergerak untuk melakukan tindakan yang produktif, baik yang berorientasi kerja untuk menghasilkan uang maupun yang tidak disebut motivasi kerja motivasi kerja yang dimiliki seorang pekerja berbedabeda tentunya, dan juga berubah-ubah.

Mahmudi (2015) mendefinisikan motivasi sebagai pekerjaan yang dilakukan oleh seorang manajer dalam memberikan inspirasi, semangat, dan dorongan kepada orang lain. Dalam hal ini karyawan untuk mengambil tindakan-tindakan. Pemberian dorongan ini bertujuan untuk menggiatkan karyawan agar mereka bersemangat dan dapat mencapai hasil sebagaimana dikehendaki oleh organisasi.

Lebih lanjut Mahmudi (2015) berpendapat bahwa motivasi adalah sikap dan nilai dasar yang dianut oleh seseorang atau sekelompok orang untuk bertindak atau tidak bertindak. Motivasi pada prinsipnya merupakan daya dorong yang kuat dalam membawa seseorang melaksanakan kebijakan manajemen yang bisa terjelma dalam perilaku antusias, berorientasi pada tujuan, dan memiliki target kerja yang jelas, baik secara individual maupun kelompok. Selanjutnya Handoko (2011) memberikan pengertian motivasi sebagai berikut: "Motivasi adalah keadaan dalam pribadi seseorang yang mendorong keinginan individu untuk melakukan kegiatan-kegiatan tertentu guna mencapai tujuan".

Motivasi merupakan faktor yang mengarahkan dan mendorong perilaku individu untuk melakukan suatu kegiatan, dapat dikatakan jika motivasi merupakan faktor dasar yang mendorong seorang karyawan untuk bekerja dengan baik. Dengan adanya motivasi yang tinggi, maka seseorang akan memberikan usaha yang lebih di dalam melaksanakan pekerjaannya sehingga menghasilkan kinerja yang lebih baik. Karena itu, perusahaan perlu melakukan upaya-upaya untuk meningkatkan motivasi karyawan guna meningkatkan kinerja karyawan. Pemberian motivasi yang tepat, dapat mendorong karyawan untuk meningkatkan kinerjanya. Hal ini seperti yang dikemukakan Siagian (2003:287) bahwa dengan motivasi yang tepat, para karyawan akan terdorong untuk berbuat semaksimal mungkin dalam melaksanakan tugasnya. Maka dari itu penting bagi perusahaan untuk memperhatikan motivasi kerja karyawan sehingga dapat menetapkan kebijakan yang dapat mendorong karyawan agar bekerja dengan baik sehingga kinerjanya meningkat. Berdasarkan deskripsi latar belakang tersebut, peneliti berasumsi pemberian motivasi yang efektif dapat menaikkan kinerja karyawan sehingga dapat memberikan pelayanan yang baik bagi masyarakat.

\section{Kinerja Karyawan}

Menurut Hasibuan (2007:94) kinerja adalah suatu hasil kerja yang dicapai seseorang dalam melakukan tugas-tugas yang dibebankan kepadanya didasarkan atas kecakapan, pengalaman, dan kesungguhan serta waktu. Pendapat ini lebih menitik beratkan pada aspek individual atau personal, di mana kinerja yang dimaksud adalah kinerja pegawai atau karyawan yang diukur melalui prestasi yang dapat dicapai oleh 
seorang pegawai dalam melaksanakan pekerjaanya. Robbins (2006:260) berpendapat bahwa hampir semua cara pengukuran kinerja mempertimbangkan hal-hal sebagai berikut :

1) Kuantitas

2) Kualitas

3) Ketepatan waktu

METODOLOGI PENELITIAN

Tempat dan Waktu Penelitian

Penelitian ini dilakukan di PT. Serambi Indonesia, pada tanggal $20-25$ Februari Februari 2019.

\section{Populasi dan Sampel}

Populasi dalam penelitian ini adalah seluruh karyawan pada PT. Serambi Indonesia yaitu sebanyak 150 orang. Penentuan jumlah sampel menggunakan rumus Slovin (Husein, 2008). Hal ini karena tidak semua karyawan dijadikan sebagai responden penelitian, dan semua karyawan mempunyai kesempatan untuk menjadi responden penelitian. Sampel dalam penelitian ini adalah sejumlah 52 orang.

\section{Pengumpulan Data}

Tahap pengumpulan data dimulai dengan responden terlebih dahulu diberi penjelasan maksud dan tujuan penelitian ini. Pengumpulan data primer dilakukan dengan memberikan kuesioner secara langsung kepada responden dan ditunggu oleh peneliti sampai selesai. Checklist kinerja karyawan diisi oleh direktur, kepala bagian dan kepala sub bagian yang ada di PT. Serambi Indonesia dengan terlebih dahulu membuat perjanjian lama waktu pengisian karena tidak bisa diselesaikan dalam waktu yang singkat.

\section{Analisis Data}

Untuk mengetahui analisis secara statistik dengan menggunakan rumus persentase yaitu:

$$
\begin{aligned}
& P=\frac{F}{N} x 100 \% \\
& \text { Keterangan: } \\
& \mathrm{P} \quad=\text { Persentase yang akan dihitung } \\
& \mathrm{F} \quad=\text { Jumlah frekuensi mortalitas jentik nyamuk } \\
& \mathrm{N} \quad=\text { Jumlah mortalitas keseluruhan jentik nyamuk } \\
& 100 \%=\text { Tetapan perhitungan. }
\end{aligned}
$$

\section{HASIL PENELITIAN DAN PEMBAHASAN Persepsi Terhadap Motivasi}

Tabel berikut ini akan menjelaskan mengenai indikator dari motivasi pada PT. Serambi Indonesia, sebagaimana dijelaskan pada tabel I berikut ini : 
Tanggapan Responden Motivasi

\begin{tabular}{|c|c|c|c|c|c|c|c|}
\hline \multirow[b]{2}{*}{ No. } & \multirow[b]{2}{*}{ Pertanyaan } & \multicolumn{5}{|c|}{ Pilihan Jawaban } & \multirow[b]{2}{*}{$\begin{array}{l}\text { Rata } \\
\text {-rata }\end{array}$} \\
\hline & & $\begin{array}{l}\text { Sgt } \\
\text { Tdk } \\
\text { Setuju }\end{array}$ & $\begin{array}{l}\text { Tdk } \\
\text { Setuju }\end{array}$ & Netral & Setuju & $\begin{array}{l}\text { Sangat } \\
\text { Sgt } \\
\text { Setuju }\end{array}$ & \\
\hline 1. & $\begin{array}{l}\text { Saya merasa puas dengan } \\
\text { suasana kerja dan lingkungan } \\
\text { kantor Serambi Indonesia }\end{array}$ & 0 & 8 & 5 & 23 & 16 & 3,90 \\
\hline 2. & $\begin{array}{l}\text { Pimpinan saya memberikan } \\
\text { status dan tanggung jawabnya } \\
\text { yang jelas kepada setiap } \\
\text { karyawan }\end{array}$ & 0 & 14 & 5 & 24 & 9 & 3,54 \\
\hline 3. & $\begin{array}{l}\text { Kompensasi yang diberikan } \\
\text { kepada setiap karyawan sudah } \\
\text { memadai dan memuaskan }\end{array}$ & 0 & 12 & 8 & 18 & 14 & 3,65 \\
\hline 4. & $\begin{array}{l}\text { Menurut saya hubungan kerja } \\
\text { dengan pimpinan berjalan } \\
\text { dengan baik }\end{array}$ & 0 & 4 & 6 & 34 & 8 & 3,88 \\
\hline 5. & $\begin{array}{l}\text { Fasilitas kerja yang diberikan } \\
\text { oleh pimpinan kepada saya } \\
\text { sangat memuaskan }\end{array}$ & 0 & 3 & 3 & 15 & 31 & 4,42 \\
\hline $\operatorname{Re}$ & & & & & & & 3,88 \\
\hline
\end{tabular}

Sumber: Data Primer, 2019 (diolah).

Berdasarkan tabel I di atas juga dapat dijelaskan bahwa variabel motivasi diperoleh nilai rerata sebesar 3.88, atau responden menyatakan setuju bahwa faktor motivasi kerja karyawan pada PT. Serambi Indonesia akan berdampak terhadap peningkatan kinerja karyawan PT. Serambi Indonesia.

\section{Persepsi Terhadap Beban Kerja}

Tabel berikut ini menjelaskan mengenai indikator dari beban kerja karyawan PT. Serambi Indonesia, sebagaimana dijelaskan pada tabel II berikut ini;

\section{Tanggapan Responden Mengenai Beban Kerja}

\begin{tabular}{|l|l|l|l|l|l|l|l|}
\hline No. & Pertanyaan & $\begin{array}{l}\text { Pilihan Jawaban } \\
\text { Sgt } \\
\text { Tdk } \\
\text { Setuju }\end{array}$ & $\begin{array}{l}\text { Tdk } \\
\text { Setuju }\end{array}$ & Netral & Setuju & $\begin{array}{l}\text { Sangat } \\
\text { Sgt } \\
\text { Setuju }\end{array}$ & $\begin{array}{l}\text { Rata } \\
\text {-rata }\end{array}$ \\
\hline 1. & $\begin{array}{l}\text { Tingkat kesulitan kerja yang } \\
\text { saya jalankan belum dapat saya } \\
\text { selesaikan secara penuh }\end{array}$ & 0 & 3 & 0 & 34 & 15 & 4,17 \\
\hline 2. & $\begin{array}{l}\text { Karena beban kerja yang tinggi } \\
\text { maka diperlukan waktu lembur } \\
\text { untuk menyelesaikan pekerjaan } \\
\text { itu }\end{array}$ & 0 & 0 & 5 & 19 & 28 & 4,60 \\
\hline 3. & $\begin{array}{l}\text { Beban kerja yang diberikan oleh } \\
\text { pimpinan harus segera } \\
\text { diselesaikan }\end{array}$ & 0 & 1 & 2 & 32 & 17 & 4,25 \\
\hline
\end{tabular}




\begin{tabular}{|l|l|l|l|l|l|l|l|}
\hline No. & Pertanyaan & \multicolumn{3}{|l|}{ Pilihan Jawaban } & & $\begin{array}{l}\text { Sangat } \\
\text { Sgt } \\
\text { Setuju }\end{array}$ & $\begin{array}{l}\text { Rata } \\
\text {-rata }\end{array}$ \\
\hline & $\begin{array}{l}\text { Sgt } \\
\text { Tdk } \\
\text { Setuju }\end{array}$ & $\begin{array}{l}\text { Tdk } \\
\text { Setuju }\end{array}$ & Netral & Setuju & & \\
\hline 4. & $\begin{array}{l}\text { Pertanggung jawab } \\
\text { kadang tidak sesuai dengan } \\
\text { tugas dan fungsi karyawan }\end{array}$ & 0 & 0 & 5 & 20 & 27 & 4,42 \\
\hline 5. & $\begin{array}{l}\text { Kondisi pekerjaan yang saya } \\
\text { alami kurang cukup baik } \\
\text { untuk dikerjakan }\end{array}$ & 0 & 1 & 5 & 31 & 15 & 4,15 \\
\hline Rerata & & & & & & 4,31 \\
\hline
\end{tabular}

Sumber: Data Primer, 2019 (diolah)

Berdasarkan tabel II di atas juga dapat dijelaskan bahwa variabel beban kerja karyawan PT. Serambi Indonesia diperoleh nilai rerata sebesar 4,31, atau responden menyatakan setuju bahwa beban kerja dapat berdampak terhadap peningkatan kinerja karyawan PT. Serambi Indonesia.

\section{Persepsi Terhadap Kinerja karyawan}

Tabel berikut ini akan menjelaskan mengenai indikator dari kinerja karyawan PT. Serambi Indonesia, sebagaimana dijelaskan pada tabel III berikut ini:

\section{Tanggapan Responden Kinerja karyawan}

\begin{tabular}{|c|c|c|c|c|c|c|c|}
\hline \multirow[b]{2}{*}{ No. } & \multirow[b]{2}{*}{ Pertanyaan } & \multicolumn{5}{|c|}{ Pilihan Jawaban } & \multirow[b]{2}{*}{$\begin{array}{l}\text { Rata } \\
\text {-rata }\end{array}$} \\
\hline & & $\begin{array}{l}\text { Sgt } \\
\text { Tdk } \\
\text { Setuju }\end{array}$ & $\begin{array}{l}\text { Tdk } \\
\text { Setuju }\end{array}$ & Netral & Setuju & $\begin{array}{l}\text { Sangat } \\
\text { Sgt } \\
\text { Setuju }\end{array}$ & \\
\hline 1. & $\begin{array}{l}\text { Pelaksanaan kegiatan } \\
\text { pelayanan telah sesuai dengan } \\
\text { prosedur yang ditetapkan, dan } \\
\text { berjalan lancer }\end{array}$ & 0 & 1 & 5 & 21 & 25 & 4,35 \\
\hline 2. & $\begin{array}{lr}\begin{array}{l}\text { Persyaratan teknis yang } \\
\text { diperlukan }\end{array} & \text { untuk } \\
\text { mendapatkan pelayanan telah } \\
\text { sesuai dengan } \\
\text { pelayanannya }\end{array}$ & 0 & 5 & 11 & 18 & 18 & 3,94 \\
\hline 3. & \begin{tabular}{llr} 
Dalam & \multicolumn{2}{r}{ memberikan } \\
pelayanan, & apakah & para \\
petugas & selalu & menepati \\
jadwal & kerjanya & sesuai \\
dengan & ketentuan & yang \\
berlaku & & \\
\end{tabular} & 0 & 0 & 8 & 22 & 22 & 4,27 \\
\hline
\end{tabular}

Lanjutan Tabel III

\begin{tabular}{|c|c|c|c|c|c|c|c|}
\hline 4. & $\begin{array}{l}\text { Dalam penyelenggaraan dan } \\
\text { pelaksanaan pelayanan, } \\
\text { nampak jelas batas tanggung } \\
\text { jawab dan wewenang setiap }\end{array}$ & 0 & 6 & 6 & 19 & 21 & 4,06 \\
\hline
\end{tabular}




\begin{tabular}{|c|c|c|c|c|c|c|c|}
\hline & petugas & & & & & & \\
\hline 5. & $\begin{array}{l}\text { Para petugas selalu bersikap } \\
\text { ramah sewaktu memberikan } \\
\text { pelayanan kepada masyarakat }\end{array}$ & 0 & 2 & 9 & 27 & 14 & 4,02 \\
\hline 6. & $\begin{array}{lr}\text { Kepastian jadwal pelayanan } \\
\text { yang diberikan } & \text { kepada } \\
\text { masyarakat sesuai } & \text { dengan } \\
\text { jenis pelayanan } & \text { yang } \\
\text { diberikan } & \end{array}$ & 0 & 4 & 15 & 25 & 8 & 3,71 \\
\hline 7. & $\begin{array}{ll}\text { Karyawan selalu mempunyai } \\
\text { tanggung jawab dalam } \\
\text { menyelesaikan } & \text { setiap } \\
\text { permasalahan } & \end{array}$ & 0 & 4 & 11 & 29 & 8 & 3,79 \\
\hline \multicolumn{7}{|c|}{ Rerata } & 4,01 \\
\hline
\end{tabular}

Sumber: Data Primer, 2019 (diolah).

Berdasarkan tabel III di atas juga dapat dijelaskan bahwa variabel kinerja karyawan PT. Serambi Indonesia diperoleh nilai rerata sebesar 4,01, atau responden menyatakan setuju bahwa responden mempunyai persepsi yang positif terhadap kinerja karyawan.

\section{KESIMPULAN}

Hasil penelitian membuktikan bahwa variabel motivasi diperoleh nilai rerata sebesar 3.88, atau responden menyatakan setuju bahwa faktor motivasi kerja karyawan pada PT. Serambi Indonesia akan berdampak terhadap peningkatan kinerja karyawan PT. Serambi Indonesia, bahwa variabel beban kerja karyawan PT. Serambi Indonesia diperoleh nilai rerata sebesar 4,31, atau responden menyatakan setuju bahwa beban kerja dapat berdampak terhadap peningkatan kinerja karyawan PT. Serambi Indonesia. bahwa variabel kinerja karyawan PT. Serambi Indonesia diperoleh nilai rerata sebesar 4,01 , atau responden menyatakan setuju bahwa responden mempunyai persepsi yang positif terhadap kinerja karyawan.

\section{DAFTAR PUSTAKA}

Handoko, T. Hani. (2011). Manajemen Sumber Daya Manusia. Yogyakarta: Badan Penerbit Fakultas Ekonomi.

Hasibuan (2012), Manajemen Sumber Daya Manusia. Edisi Revisi. PT. Bumi Aksara. Jakarta.

Husein, Umar. 2008. Metode Penelitian Untuk Skripsi dan Tesis Bisnis. Jakarta. PT Rajagrafindo Persada

Mahmudi (2015), Manajemen Kinerja Sektor Publik, Penerbit UPP AMP YKPN, Yogyakarta.

Robbins, Stephen P. (2006). Perilaku Organisasi. Edisi kesepuluh. Jakarta: PT Indeks

Kelompok Gramedia Siagian (2003:287)

Wursanto, Ignasius. 2009. Dasar-Dasar Ilmu Organisasi. Edisidua. Yogyakarta: Andi 